\title{
11. Heading for the scrap heap of history? The consequences of the coup for the Fiji labour movement
}

\author{
Vijay Naidu
}

During the period 2001-06, in between his repeated media skirmishes with Prime Minister Laisenia Qarase's government, the commander of the Republic of Fiji Military Forces (RFMF), Commodore Frank Bainimarama, proclaimed his intention to depose Qarase's Soqosoqo Duavata ni Lewenivanua (SDL) party from government. ${ }^{1}$ Even though Qarase had, for the first time, followed Fiji constitution's power-sharing provision, and established a multiparty government, with ministerial appointments for eight Fiji Labour Party (FLP) members of parliament, it was evident, from three very controversial bills, that Qarase continued to push an ethno-nationalist agenda; this was used by the Commodore as a justification for the coup.

The interim administration, with Commodore Bainimarama as prime minister, has taken its authority and legitimacy from the Office of the President of the Republic of the Fiji Islands. Fiji is not a republic in the accepted meaning of the word; it does not denote sovereignty residing in the people of the nation. Under the constitution, the President of Fiji is nominated by the unelected Bose Levu Vakaturaga (Great Council of Chiefs or GCC).

\section{Paramountcy of 'indigenous rights' coups and the 'clean-up' coup}

Fiji's 2006 coup not only bestowed near-absolute sovereignty on Fiji's President, it also caused considerable confusion and angst among those who had previously supported the overthrow of legitimately elected governments. The coups of 1987 and 2000 had been justified by the perpetrators in terms of protecting and promoting indigenous Fijian interests against those of non-ethnic Fijian citizens. In 1987, the indigenous Fijian establishment of paramount chiefs and their allies, as well as elements from the newly formed Taukei movement, took power. This was celebrated by most - but not all - indigenous Fijians. In the vanguard of support for the illegal overthrow of the coalition government that had been led by Dr Timoci Bavadra were the GCC, the Fijian Administration, indigenous Fijian public servants, ethnic Fijian trade union leaders and the leadership of the Methodist Church in Fiji and Rotuma. ${ }^{2}$

A form of quiet 'ethnic cleansing' took place after 1987. More than 100,000 Indo-Fijians emigrated in the face of institutionalized racism and the 
'ethnicization' of the State. The consequences of this loss of human capital, purchasing power, and financial capital have yet to be comprehensively measured. ${ }^{3}$ The exodus of a third of Fiji's Indo-Fijian voters almost guaranteed the victory of the dominant ethno-nationalist party in 2001, and even more so in 2006.

With the 2006 coup, things have gone topsy-turvy - the overwhelmingly indigenous Fijian military appears to have turned against the very indigenous Fijian establishment of which it has been an integral part. Both the GCC and the Methodist Church have been openly criticized and even ridiculed by the military commander. ${ }^{4}$ Indeed, the interim government suspended the GCC following its refusal to endorse the former's nominee for the position of Vice-President. Other exclusively 'Fijian' institutions, such as the Native Land Trust Board (NLTB) and the Fijian Administration, have come under close scrutiny. Not surprisingly, those previously opposed to the 1997 constitution, the practice of 'democracy' and human rights (including the deposed Prime Minister Qarase himself), have become very vocal advocates of them.

Those previously wronged by the repeated violent takeovers of elected governments have become beneficiaries of the latest coup. This applies especially to FLP leader Mahendra Pal Chaudhry. Ousted twice from government - first in 1987, when he was minister of finance in the Bavadra-led coalition government, and then in 2000, when he was prime minister - he accepted the position of minister of finance in the interim government established after the 2006 coup. $^{5}$ On the receiving end for the third time was Krishna Datt, an FLP founder and vice-president, who was a cabinet minister in the deposed governments of 1987, 2000 and 2006.

This spectacle of some individuals in the FLP (Chaudhry, Poseci Bune and Lekh Ram Vayeshnoi) benefiting from the 2006 coup by being allocated ministerial appointments, and others (Krishna Datt, Gunasagaran Gounder, Gyani Nand ${ }^{6}$ and Adi Sivia Qoro) being ousted from such positions is part of a wider schism within the FLP. Beneficiaries of the coup include Chaudhry loyalists, such as executive members of the Fiji Trade Union Congress (FTUC) who were appointed to various boards of statutory bodies. ${ }^{7}$ Felix Anthony and Daniel Urai, for example, assumed key positions in the Fiji National Provident Fund and, in those roles, exert powerful influence over the multi-million dollar Natadola tourist project in south-west Viti Levu.

The divisions in the FLP have been a product of Mahendra Chaudhry's tight and authoritarian control over its membership, and his efforts to extend his influence through his loyalists into the wider trade union movement. Persons opposed to Chaudhry's style of leadership and to his approach to issues facing the party and/or the country have been removed from the party and from the FTUC, the National Farmers Union (NFU) and the Sugar Cane Growers Council 
(SCGC). ${ }^{8}$ Chaudhry's influence on both the FLP and the labour movement has been pivotal.

\section{The labour movement}

Defining the labour movement in Fiji is at once an easy and a difficult task. In one sense the notion of a labour movement denotes organized labour - that is, unionized labour characterized by membership in trade unions (or the trade union movement) and, in the political domain, by membership in and support for the FLP. The difficulty arises from the fact that a majority of the formal sector workers in Fiji are not unionized. These include construction, garment and footwear, sawmilling and retail and service sector workers. ${ }^{9}$ Moreover, two-thirds of Fiji's labour force is in the informal sector - working for others, including as family labour - or are self-employed in the primary sector (agriculture, fisheries and forestry) and the non-formal sector. As such, they fall outside the purview of organized trade unionism. This explains the FLP directing its appeal more broadly to workers, farmers and small-business owners.

The labour force engaged in agriculture and fisheries is divided into broad categories. There are those involved as farmers and farm-workers in commercial agriculture - such as the production of sugar cane, coconut, cattle, kava, taro, ginger, fruit and vegetables. Among this segment of the labour force, only the sugar cane growers are properly unionized. They are represented by the NFU, the SCGC and the Fiji Cane Growers Association (FCGA).

While there are indigenous Fijian farmers in the commercial sector, proportionate to their population numbers they are relatively few compared with Indo-Fijians, mixed race and Chinese-Fijian farmers. Indigenous Fijians tend to be semi-subsistence cultivators who produce crops and raise animals largely for their own consumption, selling only the surplus. This category of farmers, needless to say, is not unionized, and is more directly subject to the chiefs.

The formal sector labour force is further divided between white- and blue-collar workers. The former are represented by the public service unions and the teachers and nurses unions. The latter include various factory, service and commercial workers, the very large Public Employees Union, and also hourly paid and casual workers of the state. There are extremely large differences in the terms and conditions of employment of these workers. ${ }^{10}$

Thus, the labour force in Fiji is mostly unorganized; it does not strictly constitute a nation-wide labour movement. Occupational and ethnic divisions have characterized the labour movement for much of its history. ${ }^{11}$ Nevertheless, there have been rare occasions when organized labour has exhibited unity of purpose. For example, in 1959, colonial Fiji society was shaken to its foundations by the strike and subsequent riots in Suva involving the Wholesale and Retail Workers' General Union and its supporters. Working class solidarity brought 
together coloured workers against the three large oil companies managed by Europeans and the colonial state. ${ }^{12}$ However, this solidarity was undermined by the appeals of leading Fijian chiefs to ethnic Fijian workers to eschew militant trade unionism and not be misled by 'foreigners'.

Considerable worker solidarity was also engendered by the wage freeze imposed by the Alliance Party government in 1984. The freeze was accompanied by the threat to bring out the military to provide various services if there was a general strike. The government also disbanded the tripartite forum, which had previously contributed to dialogue between the Employers' Federation, the trade unions and the State. The leadership of the FTUC, the umbrella body for all trade unions in the country at that time, realized there was little that could be done, given the unbending stance of the government and the ineffectual faction-ridden parliamentary opposition. It dawned on them that the challenge would have to be at the level of wresting state power from the ruling Alliance Party. So it was that in 1985 the FTUC sponsored the FLP. ${ }^{13}$

\section{Divisions in the labour movement}

In a matter of less than a year, the FLP became the primary opposition party, even though it did not have a single seat in Fiji's parliament. It was consistent in its criticism of Alliance Party approaches to public policy-making and to specific issues and policies. Its allegations of government corruption proved to be popular. Some National Federation Party (NFP) parliamentarians, the long-established opposition party whose support base was Indo-Fijian sugar cane farmers and small businessmen, openly identified with the FLP.

Just before the 1987 election, a coalition was cobbled together between the FLP and the NFP. ${ }^{14}$ This coalition narrowly defeated the Alliance Party, which had ruled Fiji since independence. ${ }^{15}$ However, the defeat was not accepted by many leaders or supporters of the Alliance Party. The Taukei Movement, or indigenous land-owners' movement, emerged, comprising Alliance MPs, chiefs, Methodist ministers, public servants and ethnic chauvinists. This 'nationalistic' movement began a campaign of destabilization that included marches, road blocks and fire-bombing of offices and businesses, and provided the pretext for the first military coup d'état in May of that year. ${ }^{16}$

With the overthrow of the month-old FLP/NFP government, the deposed prime minister, Dr Timoci Bavadra, led a broad-based, multi-ethnic pro-democracy movement until his untimely death in 1989. ${ }^{17}$ After a short interlude, during which Bavadra's widow, Adi Kuini, led the FLP, Mahendra Chaudhry became the face of the party. He has, over the last 18 years, assumed absolute control by promoting his loyalists, marginalizing others, and removing dissenters.

Chaudhry's road to success has been accompanied by divisions in just about every organization and movement that he has been involved in. The trade union 
movement is now deeply divided between those who support Chaudhry and those who do not. Of the close to 43,000 workers who belong to trade unions (of 112,000 formal sector workers), 24,783 belong through their trade unions to the umbrella body the FTUC, and 18,143 are members of trade unions which broke away from FTUC to form the Fiji Islands Council of Trade Unions (FICTU). ${ }^{18}$ The latter body, comprising 15 unions, was formed in August 2002. ${ }^{19}$ FICTU's President is Maika Namudu of the Fijian Teachers Union and its General Secretary is Attar Singh of the Fiji Post and Telecommunications Employees Association.

The primary reason for the split and the formation of the second umbrella organization was the close connection between the FLP and the FTUC leadership. Indeed, Chaudhry had successfully manœuvred his protégés into FTUC executive positions, marginalizing and alienating those he suspected of having ties with other political parties or who did not readily follow his wishes. Those subjected to this treatment and others not inclined to be in the Chaudhry camp formed FICTU. According to one commentator, 'The fall of the union movement can be traced back to the formation of another national body, the Fiji Islands Council of Trade Unions (FICTU). Again, this came about as a result of the politically motivated attempt by Felix Anthony, Rajeshwar Singh and others to continue to treat FTUC as an arm of the Fiji Labour Party'. ${ }^{20}$

The FTUC, led by Felix Anthony and Daniel Urai and backed by the powerful Public Service Association, has been engaged in a bitter struggle against FICTU. Anthony has repeatedly asserted that FICTU is illegal and strongly protested its recognition by the then SDL government. ${ }^{21}$ FICTU's presence was questioned at the International Labor Organization's (ILO's) 91st session in Geneva in 2003 by FTUC officials. The ILO's Credentials Committee discussed the FTUC and Fiji government submissions. The International Confederation of Free Trade Unions (ICFTU) joined in the fray on the side of FTUC. Because Attar Singh, the then general secretary of the Transport Workers Union, had been nominated to be an observer at the conference by Fiji's ministry of labour, the ILO Credentials Committee did not regard the FTUC/ICFTU's objection as justified; but the Committee expressed its concern about 'incomplete delegations' and the need to remedy this. ${ }^{22}$

A war of attrition is on-going between the two umbrella organizations. In early 2004, the FLP and the FTUC sought to wrestle control of the leadership of two key trade unions from FICTU. Dr Ganesh Chand, FLP MP, contested the position of secretary of the Bank Employees Union against Pramod Rae, who had been acting secretary. Chand was soundly defeated. Daniel Urai, another FLP MP, contested the position of general secretary of the Fiji Post and Telecommunications Employees Association against Attar Singh. Singh won with an overwhelming majority. It is noteworthy that both Rae and Singh have close connections with the NFP and are vocal opponents of Chaudhry. ${ }^{23}$ 
The tussle between Chaudhry's men and NFP supporters has also been taking place among farmers. The older farmers' union leaders had supported the idea of the NFU, initiated by the FTUC to organize rural workers in $1978 .{ }^{24}$ In the early period, James Raman, the then secretary of the FTUC, was chair of the NFU, and Chaudhry, as assistant secretary of the FTUC, became its first secretary. The objective was to establish the NFU and hand it over to the farmers. Raman relinquished his position to a respected farmer, Girja Prasad. However, Chaudhry held on to the secretary's position and replaced Prasad with his own man.

By the time sugar cane farmers loyal to NFP and NFP leaders realized that Chaudhry had used this initiative to secure a firm political base it was too late. The FCGA was formed to counter the influence of Chaudhry and his NFU. Prasad observed that, 'The Fiji Cane Growers Association was formed by the supporters of the National Federation Party partly because they felt that the National Farmers Union had become a branch of the Labour Party'. ${ }^{25}$

Through the NFU, Chaudhry has gained considerable support for the FLP and has won all the rural 'Indian' communal seats in the last three general elections. The FCGA leadership has sought to gain lost ground by frontal attacks on Chaudhry's policies and integrity. For instance, as leader of the opposition in 2005, Chaudhry opposed the SDL's efforts to reform the sugar industry and yet now, as minister of finance and the sugar industry, he pushes strongly for reform. He had previously maintained that the Indian Sugar Technology Mission's recommendation for restructuring the industry was based on an overly ambitious sugar production target of 430,000 tonnes, pointing out that sugar production had declined to 270,000 tonnes. He pointed to expiring farm leases, to the increased costs of inputs, including fertilizer, and to the impending reduction in sugar prices (from $\mathrm{F} \$ 55$ per tonne to $\mathrm{F} \$ 43$ per tonne) as the EU phased out preferential access and stopped paying well above world market price for sugar from countries such as Fiji. He argued that poor infrastructure and obsolete machinery in the mills would work against the costly reform. He said ethanol production was uneconomic. He made out that the reform was a costly waste of money. Yet, he reversed all of these positions after he joined the interim administration and took responsibility for the sugar industry.

The sugar industry, including the farmers, hoped that the injection of F\$350 million of EU funds would assist in the rejuvenation of sugar cane farming and sugar production, as well as cushion the impending 36 per cent reduction in the price of sugar. However, the EU withheld its aid to the industry because of the 2006 coup. When FCGA's Bala Dass made an issue of the plight of farmers, who he said would need subsidies to keep the sugar price at $\mathrm{F} \$ 55$ per tonne something that Chaudhry had said previously - Chaudhry called him a 'professional whiner'. Dass in turn said that Chaudhry had a 'master's degree in making false promises'. 
Kamal Iyer, in a cogently argued article, quoted Chaudhry's 2006 budget speech in which he had vigorously opposed the sugar reform initiative of Qarase's SDL government, and his contradictory position in the post-coup era. Iyer, intrigued by Chaudhry's conversion from anti- to pro-sugar reformer, raised the following rhetorical questions:

... how can the initiatives of the deposed SDL Government that Chaudhry tore to pieces have now become his baby to rescue the sugar industry? And can Chaudhry explain how the concerns that he raised on that day have now become a thing of the past as far as he is concerned? According to Dass, these problems have worsened to the extent that they are about to strangulate cane farmers and the industry. ${ }^{26}$

He concluded his piece by expressing his support for Dass:

Based on the cries emanating from the cane belts, Bala Dass may have just understated Mahendra Chaudhry's master's degree in making false promises. His qualifications are unrivalled and unparalleled.

\section{Divisions in the Fiji Labour Party}

During the last two decades, the FLP has gone through several episodes of dissension and crisis. Each crisis witnessed the departure of those who would stand up to Chaudhry and his inner circle, and to the Chaudhry circle's consolidation of power in the party. A number of academics left the party after Dr Bavadra's death. In 1992, as the FLP leadership prevaricated over whether or not to boycott the general election, many ethnic Fijian members quit the party to establish the New Labour Party.

The FLP's national council, which is dominated in its entirety by Chaudhry supporters (many of whom are NFU representatives), disciplines and otherwise undermines those who dissent. Dr Tupeni Baba, who was the deputy prime minister in the People's Coalition government and a Chaudhry loyalist, was ousted from the party after 2000. He formed the New Labour Unity Party, which won two seats at the 2001 general election - although Baba himself failed to secure the Samabula/Tamavua Open seat. Following the 2006 general election, a rift emerged between Chaudhry and a group of senior FLP members. These included Krishna Datt (an FLP vice-president), Poseci Bune (deputy leader), MPs Felix Anthony and Agni Deo Singh, and former senator Dr 'Atu Emberson Bain. It was alleged that Chaudhry had nominated his cronies and a relative or two as senators over other very competent persons. In the dispute, 17 of the 31 FLP MPs supported Poseci Bune, the acting leader, over Chaudhry. ${ }^{27}$

Chaudhry sought to discipline 'the gang of five' over their bid to nominate their preferred candidates to the senate via the office of the leader of the opposition. The five dissenters took legal action to stop the FLP national council from taking 
disciplinary action. This saga has not ended, as legal proceedings are still pending. However, with Chaudhry's stranglehold on the party, it is very likely that Krishna Datt and 'Atu Bain will have to leave. Felix Anthony, who had previously been the most vocal of the five in criticizing Chaudhry's nominations to the senate and his style of leadership, and Agni Deo Singh have apologized and confirmed their support for Chaudhry. It is apparent that intelligent and critical thinkers who might challenge the latter do not last in the party.

\section{The Fiji Labour Party and the coup}

In early 2006, months before the general election, FLP president Jokapeci Koroi was accused of encouraging the military to overthrow the SDL government. Both NFP and FICTU leaders condemned the FLP president for her statements endorsing the threats being made by the military commander against Qarase. ${ }^{28}$ An NFP leader claimed 'the FLP is now trying to return to power not through the ballot box but by the barrel of the gun'. He condemned Koroi's statement as treasonous and urged the police to investigate.

After agreeing that the FLP join the Qarase-led multiparty government following the 2006 election, and providing a list of FLP MPs to the SDL prime minister, Chaudhry initially gave lukewarm support to the multiparty government; he then turned hostile towards it. This was because, in the months following the formation of the new government, Krishna Datt emerged as the FLP leader in government. With his style of reconciliatory politics, he was quickly gaining the image of a national statesman. This did not sit well at all with Chaudhry, who was totally disinclined to being sidelined by Datt.

As the Vice-President of Fiji, Ratu Joni Madraiwiwi, in his address to the Fiji Institute of Accountants, a month after the formation of the multiparty government, had opined, Chaudhry was in a 'strategic position to destroy the multiparty government' ${ }^{29}$

Following the coup, the FLP president, in her speech to the delegates of the party's national council, declared her support for the interim administration and the need for the 'clean-up'. She appealed to FLP supporters to back the interim administration. It is evident that the FLP leadership is part of the military-backed interim government and most FLP supporters appear to be comfortable with this state of affairs. Chaudhry has been completely successful in ridding the FLP of potential threats to his leadership of the party.

Chaudhry readily accepted the position of interim minister of finance in the post-coup administration, and has used every public opportunity to roundly criticize deposed Prime Minister Qarase for mismanagement, incompetence and corruption. He has also consistently claimed that the SDL won the 2006 election through vote-rigging. He has claimed that the 2006 coup was 'warranted', 30 but regretted that it took place. It is apparent that he supports the military and 
the interim administration's 'clean-up' activities, including the establishment of the Fiji Independent Commission Against Corruption (FICAC). It is evident that he has a great deal of affinity with the coup-makers and their agenda.

\section{The labour movement's downfall}

Divisions in the trade union movement have become significant fault lines in the post-2006 coup period, and have seriously affected the labour movement's capacity to articulate common interests and meet threats to the well-being of workers under what is, in effect, a military dictatorship. The FTUC is seen to be - and has been accused of - collaborating with the military-backed regime. While FTUC leaders have enjoyed the 'perks of office' as board members of various statutory bodies - including the multi-billion dollar pension body, the Fiji National Provident Fund - their opponents in FICTU, who have opposed the regime (such as, Attar Singh, Tevita Koroi and Taniela Tabu), have been threatened, detained and even assaulted by the military. Matters came to a head in the middle of 2007 when the interim administration unilaterally imposed a five per cent across-the-board pay cut for all civil servants, reduced the compulsory retirement age from 60 to 55 years and nullified the agreement between Qarase and the public sector trade unions. The economic downturn following the coup was used as the primary justification for compelling public servants to tighten their belts.

The FTUC and its affiliates, the Fiji Public Service Association (FPSA) and the Fiji Teachers Union (FTU), were at first vociferous in their opposition to the salary cut, the reduction in the retirement age and the abrupt end to a legal agreement. They made threatening noises about strike action and about having these matters resolved in the courts. They condemned FICTU - which wanted to have discussions with the interim administration about other ways of responding to financial constraints - for 'selling out'. However, it was not long before it became clear that the FTUC and its affiliates were merely posturing. They quickly capitulated and accepted a one per cent restoration of pay. FICTU, on behalf of its affiliates, followed due process by requesting the Minister of Labour to refer the dispute to arbitration. The interim minister, whilst agreeing that FICTU and its affiliates had followed the law, did not act according to Fiji's laws. She appeared to have been instructed by the interim prime minister not to follow due process.

FICTU affiliates, having lodged the necessary notice of strike action, which was their legal entitlement, were denied the right to withdraw their labour. The military and the police resorted to intimidation. FICTU leaders decided to take legal action on the matter.

The Fiji Nursing Association, which is not affiliated to either one of the umbrella organizations, stood its ground, and its members went on strike on 25 July. 
Seven days later, the nurses were joined by hundreds of teachers and public sector workers throughout the country, by members of the Fijian Teachers Association (FTA), the Fiji Public Employees Union (FPEU) and the Viti Civil Servants Association (VCSA). The interim government refused to negotiate with the striking trade unions, maintaining that its offer of a one per cent restoration was the best available under the circumstances. The Public Service Commission made repeated announcements that striking workers would be identified and their pay deducted for the period that they were on strike. The interim government threatened to use the military, if necessary, to provide emergency services. The interim government also alleged that the unions that had gone on strike were largely ethnic Fijian in their membership and they were being politically manipulated. In the face of the interim government's extreme hard-line position, the industrial action by the Nurses Association, FTA, FPEU and VCSA began to crumble. The nurses held out the longest.

The strike failed for several reasons, but a significant factor was the lack of solidarity in the labour movement. The FTUC, the FPSA and the FTU stood by as other public sector workers withdrew their labour. The leaders of these 'by-standing' unions chose to criticize their counterparts in the striking unions for not making a deal with the interim government. Worse still, the general secretary of the FTU offered to provide scab labour if the FTA's withdrawal of its members seriously affected schools. It is likely that this gesture has ended the Fiji Teachers Confederation that had previously brought these ethnically divided unions together. Several legal challenges to the interim government's initial decisions relating to the pay cut, retirement age and the agreement between the public sector unions and the SDL government are pending. The courts have already passed the judgment that the interim government erred in its imposition of 55 years as the retirement age for public servants.

The lack of cohesion and solidarity among trade unions, in the face of a heavy-handed authoritarian State, has also jeopardized possibilities of gains for non-unionized workers in the formal sector, as well as put at risk new industrial relations legislation. With the coup, all Wages Councils have been suspended. ${ }^{31}$ This means that this avenue for adjusting non-unionized workers' wages and other conditions of work has vanished. With this suspension, possibilities of reforming the Wages Councils to better reflect worker needs have also been brought to an abrupt halt. The divided trade union movement has been silent on this critical issue.

On the matter of the new industrial relations bill, the Employment Relations Bill, the labour movement schism is openly expressed. The FTUC is completely in support of it, arguing on the interim government side that it marks the dawning of a new era in positive labour relations. For the FTUC, this bill has taken nine years to reach this stage and there should be no further delay in its 
promulgation. In contrast to the FTUC stand, FICTU considers any expeditious passage of the bill into law as totally unacceptable. For the latter, the bill should not be made into law by what it considers to be an illegal regime. It would also like to review certain provisions of the bill, such as the apparent dilution of the right to strike, and limit on the number of times that women employees can take maternity leave. While there is certainly some basis for questioning aspects of the bill, the underlying lack of agreement between the two umbrella bodies has to do with their different standpoints relating to the regime in power. This difference does not contribute to cohesion in the labour movement or to furthering workers' interests at a time when their rights are under serious danger. $^{32}$

Needless to say, the current period is not conducive to the formation of new unions or the recruitment of new members to existing unions. Meetings and rallies require the approval of authorities - and even when such gatherings have been sanctioned, there is a heavy police presence.

The lack of unity in the labour movement is also affecting broader initiatives that generate awareness of work-related and workers' rights issues. Seminars, workshops, training and worker education programs, normally part of the annual routine activities of the FTUC, have been severely curtailed since the 2006 coup. Many of these activities received funding and technical support from donor agencies, such as the EU and the ILO. In the current post-coup period there is a reduction in aid funding for the country in general as well as for specific areas, such as trade union activities.

The FLP lost the high moral ground when Chaudhry took up the position of interim minister of finance in the interim administration. Chaudhry loyalists and FLP diehards believe that he did so to help the country out of the mess created by Qarase and his SDL colleagues. They have been looking forward to revelations of massive cases of corruption in the 'clean-up' campaign but, thus far, very little evidence against any former senior government officials has surfaced. On the contrary, Chaudhry himself is caught up in massive public recrimination over the revelation that he is the interim minister who has allegedly evaded paying taxes over three years and who has bank accounts in Australia holding A \$1.6 million received from, amongst other places, India. ${ }^{33}$

There are deep divisions in the party, the trade union movement and among farmers. These rifts are unlikely to be healed in the short to intermediate term. For instance, at the FLP's National Council meeting in Ba on 16 February 2008, the president of the Nadi Branch of the party, Bijay Prasad, a former FLP senator (a Chaudhry loyalist) tried to question the party leader about his overseas bank accounts and the tax evasion allegations that were aired by the media. He walked out of the meeting because of the hostile reception he received from other members of the National Council. According to Prasad: 
Everything Chaudhry is doing now is against the FLP manifesto. The FLP was formed to look after the poor. Now people are paying more than what they earn and Chaudhry being there [in the interim Government] for 14 months, hasn't done anything about it... His puppets will not speak against him but it's time that somebody does. Enough is enough!

Prasad alleged that Chaudhry 'even went as far as stopping the multimillion dollar project at Momi Bay, which now sees villagers without jobs'. ${ }^{4}$ Prasad claimed that the FLP's involvement in the interim administration has 'widened the racial gap'. ${ }^{35}$ Baba, when interviewed on the exposé of Chaudhry's alleged tax evasion and overseas bank accounts, stated that he and others had raised issues relating to the outcomes of the FLP's overseas fund-raising efforts but had not been not given a satisfactory response. ${ }^{36}$ 'It has split the party and caused many of his colleagues to be kicked out of the party'. Baba called for Chaudhry's resignation from the party and as interim minister of finance, saying, 'Fiji no longer needs Chaudhry. Fiji politics without him will be cleaner, less racially polarised and congenial'. ${ }^{37}$

Thus far, there is really no significant challenge to Chaudhry's leadership from within the party. 38

While the FLP is likely to continue as an Indo-Fijian political party, with Chaudhry continuing to have considerable influence in its affairs, it has lost its credibility and its appeal to the wider Fiji society. It is now almost completely an ethnic party and will not be seen as the party of workers and disadvantaged people of the country for some time. With the declining proportion of Indo-Fijians in the total population of Fiji, it is near impossible for the FLP to win a sufficient number of seats in parliament in any future election to be able to form government. When it was first formed, the FLP's future lay in its multi-ethnic appeal; but with Chaudhry or one of his protégés at the helm, the party will have no credibility among ethnic Fijians and other minorities.

In its present form and orientation, the FLP is very likely to be embroiled in the quicksand of divisive trade union politics and the quagmire of sugar cane politics. The latter has served Chaudhry's political ambitions well, but anti-Chaudhry sentiments are growing. Ethnicity rather than class will continue to take centre stage for the party, thereby undermining its capacity at the national level.

\section{Phoenix rising?}

In the current post-coup period the labour movement is seriously weakened by the divisions among trade unions, farmers' organizations and within the FLP itself. Mahendra Pal Chaudhry has contributed immensely, both to the party's impact on the national political arena and to its present ethnic character. He has also been the main protagonist in causing the rifts in the organizations of the working people of the country. The FLP under Chaudhry has abandoned low-paid 
workers in favour of a more exclusive ethnic appeal to Indo-Fijian voters. It is only with his departure from national politics and from meddling in the affairs of trade unions and farmers' associations that a degree of unity will return to the labour movement.

It is only a matter of time before the broader, disadvantaged workforce's efforts for better conditions permeate national politics, and the labour movement is resuscitated. This revived labour movement will become even more multi-ethnic as the forces of globalization mould Fiji in the interest of international capital, creating the conditions for a political party in the image of the FLP when it was formed two decades ago. With short-term seasonal labour migration beginning to be implemented by New Zealand and Australia, it may even take more international dimensions. A new era of collaboration amongst labour movements in Oceania may even be engendered. This might be too optimistic a prognosis as, after the debacle of the last two years, it may take the next 25 years for Fiji's labour movement to regain its strength.

\section{ENDNOTES}

1 Pareti, S. and Fraenkel, J. 2007. 'The strategic impasse: Mahendra Chaudhry and the Fiji Labour Party', in Fraenkel, J. and Firth, S. (eds) 2007. From Election to Coup in Fiji: the 2006 campaign and its aftermath, IPS Publications, Suva, and Asia Pacific Press, Canberra, p. 38.

2 Robertson, R. and Tamanisau, A. 1988. Fiji: Shattered Coups, Pluto Press, Leichhardt.

3 Reddy. M., Mohanty, M. and Naidu, V. 2004. 'Economic Cost of Human Capital Loss from Fiji: Implications for Sustainable Development', International Migration Review, 38, 4, Winter:1447-61.

4 Bainimarama expressed his disdain for the chiefs by suggesting that 'chiefs should go and drink home brew under a mango tree' (The Fiji Times, 20 and 23 February 2007).

5 There are two main views about Chaudhry's accepting the position of interim minister of finance: First, that he was part of a coup conspiracy that began well before the August 2006 general election; and, second, that he was invited to join Commodore Bainimarama's interim government after the 2006 coup and saw it as an opportunity to push his policies and his people into prominence. Both standpoints consider him as the 'brains' behind the interim administration. His alleged tax evasion over three years and failure to disclose A\$1.6 million lodged in Australia, provide another possible rationale for his joining the interim administration (The Fiji Times, 23 February 2008).

6 Mr Nand, a retired civil servant and diplomat, passed away in 2007.

7 The FTUC's opposition to the 2006 coup is muted, a stance which is very different from its policy of open opposition to previous coups.

8 The CEO of the Sugar Cane Growers Council, Jaganath Sami, an opponent of Chaudhry, was summarily dismissed from office by a Presidential decree. He was subsequently forcefully removed and assaulted by members of the RFMF. Sami has been replaced by Jai Gawendar, a former FLP MP.

9 These non-unionized formal sector workers are supposed to have some protection with respect to their wages through the mechanism of Wages Councils, comprising representatives of employers, trade union and government. According to a recent study (Narsey, W. 2006. Just living Wages for Fiji: lifting workers out of poverty, ECREA, Vanuavou Publications, Suva) Wages Councils have generally been ineffective and, over the last four decades of Fiji's independence, more than F\$1 billion that should have been part of workers' wages have gone to their employers. Even the modicum of wage support that Wages Councils may have provided has been lost with their suspension since the 2006 coup.

10 Narsey, W. 2007. Report on the 2004-2005 Employment and Unemployment Survey, Fiji Islands Bureau of Statistics, Vanuavou Publications, Suva.

11 For instance, there are two teachers' unions, the Fiji Teachers Union (FTU), which has open membership but is primarily Indo-Fijian, and the Fijian Teachers Association (FTA), which restricts its membership to ethnic Fijians and Rotumans. The Viti Civil Servants Association, like FTA, is ethnically 
exclusive and was formed after the 1987 coup by indigenous Fijian public servants opposed to the position taken by the Chaudhry-led Fiji Public Servants Association (FPSA).

12 See, for example, Narayan, J.1984. The Political Economy of Fiji, South Pacific Review Press, Suva; Sutherland, W. 1992. Beyond the Politics of Race, Political and Social Change Monograph 15, Department of Political and Social Change, Research School of Pacific Studies, Australian National University, Canberra; Heartfield, J. 2002. 'The Dark Races Against the Light? Official Reaction to the 1959 Fiji Riots', Journal of Pacific History 37(1):75-86.

13 See, for example, Naidu, V. 1985. 'The Fiji Labour Party and the By-Election of November 1985: A Report', Working Paper 3, SSED, University of the South Pacific, Suva; Naidu, V. 1987. 'Fiji : The State, Labour Aristocracy and the Fiji Labour Party', in Hooper, A. et al. (eds), Class and Culture in the South Pacific, Centre for Pacific Studies, University of Auckland and Institute of Pacific Studies, Auckland and Suva; Howard, M.C. 1991. Fiji; Race and Politics in an Island State, University of British Columbia Press, Vancouver.

14 Some FLP members strongly opposed the idea of a coalition with a largely ethnic party that had failed to defend worker interests during the wage freeze (see Robertson and Tamanisau 1988).

15 A palace coup by the Governor General, Ratu George Cakobau, ensured continued Alliance Party rule after its narrow defeat by the NFP in April 1977.

16 Rabuka, S.L. 2000. 'The Fiji Islands in transition: personal reflections', in Lal. B.V. (ed.) Fiji before the storm: elections and the politics of development, Asia Pacific Press, Canberra.

17 Leckie, J. 1997. To Labour with the State: The Fiji Public Service Association, University of Otago Press, Dunedin.

18 The commonly used figure of 43,000 trade unionists in Fiji is derived from adding together the claimed members of the FTUC and FICTU. Other estimates are lower. Labour Minister in the 2001-06 Qarase government Kenneth Zinck has suggested 35,000: 'there are at least 112,000 formal workers in this country and 35,000 of them are members of unions, which constitute 31 per cent. He said the remaining 70 per cent do not belong to any union at all' ('Stop fighting, protect workers, unions told', Indian News -NZ 30 May 2003).

19 Indian News, http://www.theindian.co.nz/testing/plugin/news/journal/plugin.asp?plugin= article_view_Unwrap.asp\&abxyk945=301\&iabspos $=157 \&$ vjob $=$ vsub $\% 2$ C66

${ }^{20}$ Prasad, J. 2007. 'The Role of Hindu and Muslim Organizations during the 2006 election', in Fraenkel and Firth, 2007.

21 Interestingly enough, it was the then Minister of Labour, Kenneth Zinck, who launched FICTU in August 2002.

22 The ILO's Credentials Committee also considered an objection of Fiji's Employers' Federation against the inclusion of the Fiji Chamber of Commerce representative in the tripartite delegation from Fiji.

23 Radio New Zealand International, 29 March, 2004

http://www.rnzi.com/pages/news.php?op=read\$id=9234

24 Historically, there have been at least 14 different sugar cane farmers' unions (http://en.wikipedia.org/wiki/Sugar_Cane_Farmers_Unions_in_Fiji)). Currently there are at least 4: NFU, FCGA, Kisan Sangh and an organization representing indigenous Fijian cane farmers.

25 Prasad, B.C. 2007. 'Trade Unions', in The Fiji Times, 30 August 2007.

26 The Fiji Times, 23 January 2008.

27 Radio New Zealand International 4-7 July 2006

28 Pareti, S. and Fraenkel, J. 2007. 'The strategic impasse: Mahendra Chaudhry and the Fiji Labour Party', in Fraenkel, J. and Firth, S. 2007.

29 Pareti, S. and Fraenkel, J. 2007. 'The strategic impasse: Mahendra Chaudhry and the Fiji Labour Party', in Fraenkel, J. and Firth, S. 2007, p. 101.

30 Fraenkel, J. 2007, 'The Fiji coup of December 2006: who, what, where and why?', in Fraenkel, J. and Firth, S., 2007, p. 435.

31 According to poverty survey results reported in the 1997 UNDP Fiji Poverty Report and the 2002-03 Household Income and Expenditure Survey Report (see, Narsey, W. 2006. Report on the 2002-03 Household Income and Expenditure Survey, Vanuavou Publications, Suva) more than 46 per cent of those living below the poverty line are workers; for the coup-makers one of the reasons for the overthrow of the democratically elected government was social justice for the disadvantaged! 
32 The Fijian economy experienced a decline of 6.6 per cent in 2007 and the anticipated growth for 2008 has been revised downwards to 2 per cent. Fiji's labour market has not expanded and many workers have lost jobs over the last four years in the garment and footwear, and construction industries. The coup has had a negative impact on tourism-related employment. There is downward pressure on existing wage levels.

33 The Fiji Times, 23 February 2008. His lawyers have advised the interim minister of finance to sue The Fiji Times for one billion dollars for defamation (The Fiji Times, 4 March, 2008) and have informed all media outlets that they would be liable for any further disclosure or discussion on the matter. Chaudhry himself has said that he owes no tax to the Fiji Islands Revenue and Customs Authority (FIRCA) and he is entitled to hold overseas bank accounts and invest abroad.

34 http://www.fijilive.com/news_new/index.php/news/show_news/2011

35 The Fiji Times, 11 February 2008.

36 Dr Baba joined the SDL and was an unsuccessful candidate in the 2006 election. He was subsequently appointed to be Fiji's ambassador to the United Nations, but this was overruled by the interim administration.

37 The Fiji Times, 24 February 2008.

38 The interim Prime Minister, Commodore Voreqe Bainimarama, has refused to suspend or sack Chaudhry, instead it appears that he has taken action against his Military Council spokesmen for informing the media that the Council has asked that Chaudhry 'step aside' and an independent commission of inquiry be instituted about his alleged tax evasion and his overseas bank accounts. 